\title{
KUAT TEKAN DAN TARIK BELAH PADA BETON YANG MENGGUNAKAN AGREGAT KASAR LIMBAH PLASTIK
}

\author{
Erniati Bachtiar ${ }^{1 *}$, Muh Arief Muzakkir ${ }^{1}$, Takwin $^{2}$, Sri Gusty ${ }^{1}$, Nur Khaerat Nur ${ }^{1}$ \\ ${ }^{1}$ Prodi Teknik Sipil, Fakultas Teknik, Universitas Fajar \\ ${ }^{2}$ Magister Rekayasa Infrastruktur dan Material, Fakultas Pasca Sarjana, Universitas Fajar \\ *Korespondensi: erni@unifa.ac.id
}

\begin{abstract}
Plastic represent thousands of materials with different physical, mechanical, and chemical properties. As plastic demand and usage increase, it is undeniable that the amount of plastic waste will increase. Plastic has the features of which cannot rot; it does not decompose naturally; it cannot absorb water or cannot rust. So it will eventually cause problems for the environment. This study aims to determine the compressive strength and tensile strength of concrete mixes that use coarse aggregates of plastic waste as a substitute for natural aggregates / broken rocks. There are three variations of samples made with mutations in the type of plastic used, namely PP (Polypropylene) plastic, PET (Polyethylene Terephthalate) plastic, and PP \& PET combination plastic. The specimen is cylindrical, with a size of $10 \mathrm{~cm} \times 20 \mathrm{~cm}$. Compressive strength and tensile strength testing is carried out at 28 days according to SNI standards. The results obtained the compressive strength obtained on each variation of standard concrete samples, PP aggregate concrete, PET aggregate concrete, and $P P \& P E T$ aggregate concrete, respectively, of $21.64 \mathrm{MPa}, 10.61 \mathrm{MPa}, 8.48 \mathrm{MPa}$, and $10.18 \mathrm{MPa}$. Whereas for the splitting tensile strength of standard concrete, PP aggregate concrete, PET aggregate concrete, and PP \& PET aggregate concrete respectively were $2.86 \mathrm{MPa}, 1.80 \mathrm{MPa}, 1.70 \mathrm{MPa}$, and $1.80 \mathrm{MPa}$.
\end{abstract}

Keywords : Plastic concrete, PP (Polypropylene), PET (Polyethylene Terephthalate)

\section{PENDAHULUAN}

Penggunaan material beton dalam pembangunan konstruksi semakin meningkat sehingga berefek langsung pada peningkatan kebutuhan material penyusun beton. Beton merupakan salah satu material bangunan yang diperoleh dengan menggabungkan dari beberapa material penyusun yang terdiri dari semen, agregat halus, agregat kasar dan air serta bahan additive jika dibutuhkan. Material penyusun beton paling banyak adalah agregat kasar. Umumnya kebutuhan agregat kasar berkisar $65 \%-80 \%$ dari jumlah volume beton. Kebutuhan material agregat kasar tersebut memicu penambangan batuan sebagai salah satu bahan pembentuk beton secara besar-besaran. Dengan demikian jika ini berlanjut terus, maka ketersedian sumber alam semakin berkurang yang tersedia untuk keperluan pembetonan dan disamping itu merusak lingkungan. Untuk itu perlu alternatif yang dapat digunakan untuk mengatasi masalah tersebut dengan cara mencari pengganti agregat kasar tersebut.

Sampah merupakan masalah yang sangat kompleks di daerah perkotaan. Kebutuhan plastik sebagai wadah yang cukup simpel diminati. Data BPS tahun 1999 menunjukkan bahwa volume perdagangan plastik impor Indonesia, terutama polypropylene (PP) pada tahun 1995 sebesar 136.122,7 ton sedangkan pada tahun 1999 sebesar 182.523,6 ton, sehingga dalam kurun waktu tersebut terjadi peningkatan sebesar $34,15 \%$. Jumlah tersebut diperkirakan akan terus meningkat seiring dengan waktu. Sebagai konsekuensinya, peningkatan limbah plastikpun tidak terelakkan. Hartono (1998) menjelaskan bahwa komposisi sampah atau limbah plastik memiliki sifat-sifat antara lain tidak dapat membusuk, tidak terurai secara alami, tidak dapat menyerap air, maupun tidak dapat berkarat, dan pada 
akhirnya menjadi masalah bagi lingkungan [1]. Untuk itu perlu adanya penanganan khusus terhadap sampah plastik. Salah satu faktor yang menyebabkan rusaknya lingkungan hidup sampai saat ini masih tetap menjadi "PR" besar bagi bangsa Indonesia adalah faktor pembuangan limbah sampah plastik. Plastik telah mejadi sampah yang berbahaya dan sulit dikelola. Diperlukan waktu puluhan bahkan ratusan tahun untuk menjadi sampah bekas plastik itu benar-benar terurai. Namun yang menjadi persoalan adalah dampak negatif saampah plastik ternyata sebesar fungsinya juga. Dibutuhkan waktu 1000 tahun agar plastik dapat terurai oleh tanah secara terdekomposisi atau terurai dengan sempurna. Ini adalah sebuah waktu yang sangat lama. Saat terurai, partikel-partikel plastik akan mencemari tanah dan air tanah. Jika dibakar, sampah plastik akan menghasilkan asap beracun yang berbahaya bagi kesehatan yaitu jika proses pembakarannya tidak sempurna, plastik akan mengurai di udara sebagai dioksin. Senyawa ini sangat berbahaya bila terhirup manusia. Dampaknya antara lain memicu penyakit kanker, hepatitis, pembengkakan hati, gangguan sistem saraf dan memicu depresi. Sampah plastik juga menyebabkan banjir, karena menyumbat saluran-saluran air, tanggul sehingga mengakibatkan banjir bahkan yang terparah merusak turbin waduk. Selain itu, pembuangan sampah plastik ke sungai dan laut yang menyebabkan ekosistem yang ada bisa rusak atau terputus.

Perkembangan teknologi beton semakin populer dengan adanya bahan tambah yang diberikan pada beton baik itu berupa bahan kimia, fly ash, abu ampas tebu, styroform, serta polimer. Bahan tambah polimer dalam pembuatan campuran beton merupakan zat kimia yang terdiri dari satu molekul-molekul yang besar yang terdiri dari karbon dan hidrogen sebagai molekul utamanya (S.U. Dewi dan R. Purnomo 2019). Bahan yang bersifat polimer sangat banyak didalam kehidupan yakni tanah lempung, limbah plastik yang di daur ulang. Fly ash dimana penggunaan bahan tersebut dapat dimanfaatkan baik sebagai pengganti semen maupun sebagai agregat. Erniati dkk memaparkan bahwa potensi fly ash sebagai bahan polimer dalam pengganti semen baik sebagian/seluruhnya pada campuran beton sangat besar dan dengan memanfaatkan fly ash tersebut sebagai material ramah lingkungan [2,3]. Disamping itu penelitian dengan memanfaatkan plastik, bahwa pemanfaatan limbah plastik sebagai agregat halus dalam pembuatan campuran beton telah dilakukan oleh S Das dkk (2019) dengan hasil bahwa semakin tinggi presentase plastik maka semakin menurun kekuatannya [4]. Lestariono dan Mahendya (2008) telah meneliti tentang penggunaan limbah botol plastik (PET) sebagai campuran beton untuk meningkatkan kapasitas tarik belah dan geser [5]. Penelitian oleh F.F Ridwan dkk (2014) dan Suwarno dkk (2015) bahwa cacahan limbah plastik sebagai agregat halus pada campuran beton dengan meningkatkan kuat tarik pada beton [6,7]. Penelitian agregat buatan dari limbah plastik juga telah dilakukan sebelumnya oleh Bagas Soebandono dkk (2013), Supratiknodan Ratnanik (2009), Erniati dan Asrar (2019), dan Erwin Rommel (2013) dengan hasil potensi daur ulang limbah plastik sebagai agregat kasar pada campuran beton juga sangat baik untuk struktur ringan [8,9,10,11]. Sari Utama Dewi dan Rudi Purnomo (2016) bahwa penambahan 10\% $-15 \%$ limbah plastik HDPE pada beton maka mengakibatkan kualitas beton menurun namun pPenambahan limbah plastik pada persentase 5 $\%$ selalu menghasilkan nilai kuat tekan lebih tinggi dari pada beton normal atau beton tanpa campuran [12]. Dengan demikian pemikiran pemanfaatan limbah plastik sebagai agregat pada beton sangat tepat dalam peduli lingkungan. Dimana daur ulang limbah plastik bisa mengganti sebagian maupun seluruhnya agregat pada campuran beton dengan harapan limbah plastik dapat didaur ulang sehingga sampah plastik tidak menumpuk dan merusak lingkungan serta material ramah lingkungan

Paper ini membahas nilai kuat tekan dan kuat tarik belah yang menggunakan daur ulang limbah plastik. Penelitian ini menggunakan variasi jenis limbah plastik PET (Polyethylene Terephthalate) dan PP (Polypropylene) serta gabungan PET \& PP.

\section{METODE PENELITIAN}

Penelitian ini menggunakan metode eksperimen baik dalam pengumpulan data karakterisasi material penyusun beton ringan. Pembuatan sampel dan pengujian dilaksanakan di Laboratorium Struktur dan Bahan Program Studi Teknik Sipil Fakultas Teknik Universitas Fajar. 
Pelaksanaan penelitian ini dibagi menjadi beberapa tahapan yaitu persiapan bahan, mix design, pembuatan benda uji, perawatan, dan pengujian.

\subsection{Persiapan Bahan \& Alat}

Pada tahap ini seluruh bahan dan alat yang dibutuhkan dipersiapkan terlebih dahulu. Adapun bahan-bahan dasar yang digunakan dalam penelitian ini adalah semen tipe PCC (Portland Composite Cement), Agregat halus (pasir), agregat kasar (kerikil), limbah plastik PET (polyethylene terephthalate) dan PP (polypropylene), dan air bersih.

Khusus untuk agregat buatan limbah plastik dibuat dengan ada beberapa tahapan yakni :

a. Pengumpulan limbah plastik yang telah dikumpulkan dari berbagai sumber.

b. Pencucian limbah plastik dan dibersihkan dari benda-benda lain dan kotoran yang menempel.

c. Limbah plastik yang telah dibersihkan kemudian dicacah menjadi potongan-potongan kecil sekitar $0,5 \mathrm{~cm}-$ $2 \mathrm{~cm}$ dengan menggunakan mesin pencacah plastik.

d. Cacahan limbah plastik kemudian dipanaskan hingga meleleh.

e. Setelah itu tunggu beberapa waktu sampai lelehan tersebut dingin dan mengeras.

f. Setelah mengeras dan dingin lalu dilakukan pemecahan sehingga membentuk agregat kasar dengan ukuran seperti batu pecah yakni ukuran $0,5 \mathrm{~cm}-2$ $\mathrm{cm}$. Agregat yang telah dicacah tersebut itulah yang disebut agregat buatan dari limbah plastik.

Material penyusun beton sebelum digunakan dilakukan pengujian karakteristik material agregat halus dan agregat kasar berdasarkan standar SNI. Ini sangat penting dilakukan, jika material tersebut tidak memenuhi syarat maka material tersebut tidak digunakan dalam pembuatan beton. Hasil pengujian karakteristik agregat halus dapat dilihat pada Tabel 1, sedangkan hasil pengujian karakteristik agregat kasar dapat dilihat pada Tabel 2.

Tabel 1 dan Tabel 2 memperlihatkan rekapitulasi dari hasil uji karakteristik material penyusun agregat kasar dan agregat halus, dimana hasilnya terlihat bahwa telah memenuhi syarat sebagai material penyusun beton. Dalam penelitian untuk pengujian kadar lumpur itu dilakukan pengujian dua kali karena hasil awal tidak memenuhi syarat kadar lumpur sebesar 8,5\%, melebihi dari 5\% kadar lumpur, sehingga dilakukan pencucian agregat halus kemudian di uji lagi dan telah memenuhi syarat sebagai material penyusun beton.

Tabel 1. Rekapitulasi Hasil Pengujian Karakteristik Agregat Halus

\begin{tabular}{|c|c|c|c|}
\hline No & Jenis Pengujian & $\begin{array}{l}\text { Hasil } \\
\text { Pengujian } \\
\text { Agregat Halus }\end{array}$ & $\begin{array}{l}\text { Interval } \\
\text { (SNI) }\end{array}$ \\
\hline 1 & Kadar Lumpur & $0,74 \%$ & $0,2 \%-5 \%$ \\
\hline 2 & Kadar Air & $4,93 \%$ & $3 \%-5 \%$ \\
\hline \multirow[t]{3}{*}{3} & Berat Volume & & \\
\hline & a. Kondisi Lepas & $1,41 \mathrm{~kg} /$ liter & $\begin{array}{l}1,4-1,9 \\
\mathrm{~kg} / \mathrm{liter}\end{array}$ \\
\hline & b. Kondisi Padat & $1,57 \mathrm{~kg} / \mathrm{liter}$ & $\begin{array}{l}1,4-1,9 \\
\mathrm{~kg} / \text { liter }\end{array}$ \\
\hline 4 & Absorpsi & $1,21 \%$ & $0,2-2 \%$ \\
\hline \multirow[t]{4}{*}{5} & Berat Jenis & & \\
\hline & a. Bj. Nyata & $2,88 \%$ & $1,60-3,30$ \\
\hline & b. Bj. Dasar Kering & $2,72 \%$ & $1,60-3,31$ \\
\hline & $\begin{array}{ll}\text { c. Bj Kering } \\
\text { Permukaan }\end{array}$ & $2,78 \%$ & $1,60-3,32$ \\
\hline 6 & Modulus Kehausan & $3,06 \%$ & $2,3-3,1$ \\
\hline 7 & Kadar Organik & No. 2 & $<$ No.3 \\
\hline
\end{tabular}

Tabel 2. Rekapitulasi Hasil Pengujian Karakteristik Agregat Kasar

\begin{tabular}{|c|c|c|c|}
\hline No & Jenis Pengujian & $\begin{array}{l}\text { Hasil } \\
\text { Pengujian } \\
\text { Agregat Kasar }\end{array}$ & $\begin{array}{l}\text { Interval } \\
\text { (SNI) }\end{array}$ \\
\hline 1 & Kadar Lumpur & $0,60 \%$ & Maks $1 \%$ \\
\hline 2 & Kadar Air & $1,52 \%$ & $0,5 \%-2 \%$ \\
\hline \multirow[t]{3}{*}{3} & Berat Volume & & \\
\hline & a. Kondisi Lepas & $1,64 \mathrm{~kg} /$ liter & $\begin{array}{l}1,6-1,9 \\
\mathrm{~kg} / \text { liter }\end{array}$ \\
\hline & b. Kondisi Padat & $1,77 \mathrm{~kg} /$ liter & $\begin{array}{l}1,6-1,9 \\
\mathrm{~kg} / \text { liter }\end{array}$ \\
\hline 4 & Absorpsi & $3,91 \%$ & Maks 4\% \\
\hline \multirow[t]{4}{*}{5} & Berat Jenis & & \\
\hline & a. Bj. Nyata & $2,67 \%$ & $1,60-3,33$ \\
\hline & b. Bj. Dasar Kering & $2,42 \%$ & $1,60-3,33$ \\
\hline & $\begin{array}{ll}\text { c. Bj Kering } \\
\text { Permukaan }\end{array}$ & $2,51 \%$ & $1,60-3,33$ \\
\hline 6 & Modulus Kehausan & $6,98 \%$ & $6-7,1$ \\
\hline 7 & Keausan & $31 \%$ & Maks $50 \%$ \\
\hline
\end{tabular}

\subsection{Mix Design \& Pembuatan Benda Uji}

Untuk mengetahui banyaknya bahan yang diperlukan maka dilakukan perhitungan mix design berdasarkan massa jenis dari 
masing-masing bahan. Perencanaan campuran beton menggunakan metode Standar Nasonal Indonesia (SNI 03-2838-2000). Kuat tekan (f'c) yang direncanakan $20 \mathrm{MPa}$. Komposisi dari setiap material yang digunakan berdasarkan hasil perhitungan mix design dapat dilihat pada Tabel 3 .

Tabel 3. Komposisi Campuran Material Beton Untuk $1 \mathrm{~m}^{3}$

\begin{tabular}{cc}
\hline Bahan Beton Normal & Berat $(\mathrm{Kg})$ \\
\hline Semen & 450 \\
Pasir & 666,75 \\
Kerikil & 1238,25 \\
Air & 225 \\
\hline
\end{tabular}

a. Untuk Sampel Beton Normal

Bahan yang telah disiapkan, dimasukkan kedalam mixer. Pertama-tama kerikil dan pasir dimasukkan, kemudian semen dimasukkan. Setelah ketiga bahan telah dimasukkan dan tercampur rata, air dimasukkan sedikit demi sedikit sambil diaduk dan terus diaduk hingga semua bahan tercampur homogen. Sampel beton ini sebagai standar yang tidak menggunakan material agregat plastik tapi beton standar yang diberi nama beton normal (BN).

\section{b. Untuk Sampel Beton Dengan Agregat Plastik}

Bahan yang telah disiapkan, dimasukkan kedalam mixer. Agregat buatan limbah plastik akan mengganti $100 \%$ jumlah agregat kasar pada campuran beton. Variasi sampel agregatt plastik di bagi menjadi tiga variasi yaitu beton yang menggunakan agregat buatan palstik PP diberi nama beton PP, beton yang menggunakan agregat buatan palstik PET diberi nama beton PET, dan beton yang menggunakan agregat buatan plastik gabungan PET \& PP diberi nama beton PET \&PP.

Pertama masukkan pasir dan agregat limbah plastik kemudian semen dimasukkan. Setelah ketiga bahan telah dimasukkan dan tercampur rata, air dimasukkan sedikit demi sedikit sambil diaduk dan terus diaduk sehingga bahan tercampur secara homogen. Selanjutnya campuran homogen tersebut dicetak kedalam silinder. Ukuran silinder yakni diameter $100 \mathrm{~mm}$ dan tinggi $200 \mathrm{~mm}$.

Pada proses pembuatan benda uji baik sampel beton normal maupun beton dengan menggunakan agregat buatan limbah plastik, sebelum benda uji dicetak terlebih dahulu dilakukan pengujian slump test. Hasil pengujian nilai slump test diperoleh berkisar antara $80 \mathrm{~cm}-100 \mathrm{~cm}$. Nilai slump test yang dicapai memenuhi syarat standar campuran yang baik yaitu $7,50 \mathrm{~cm}$ sampai dengan 15,00 $\mathrm{cm}$.

\subsection{Perawatan}

Benda uji yang telah dikeluarkan dari cetakan, dilakukan perawatan terhadap benda uji tersebut. Perawatan ini dilakukan dengan cara merendam benda uji kedalam bak perendam. Perawatan beton berfungsi untuk menjaga agar permukaan beton selalu lembab sehingga proses hidrasi berlangsung dengan baik dan proses pengerasan terjadi sempurna dengan ditandai tidak terjadinya retak-retak pada beton dan mutu beton dapat terjamin.

\subsection{Pengujian}

Penelitian ini dilakukan 2 (dua) pengujian mekanik yakni uji kuat tekan dan kuat Tarik belah. Pengujian kuat tekan dan tarik belah dilakukan pada sampel beton pada saat berumur 28 hari dengan menggunakan standar SNI.

\section{HASIL DAN PEMBAHASAN \\ 3.1 Berat Beton}

Berat beton sangat berpengaruh kepada

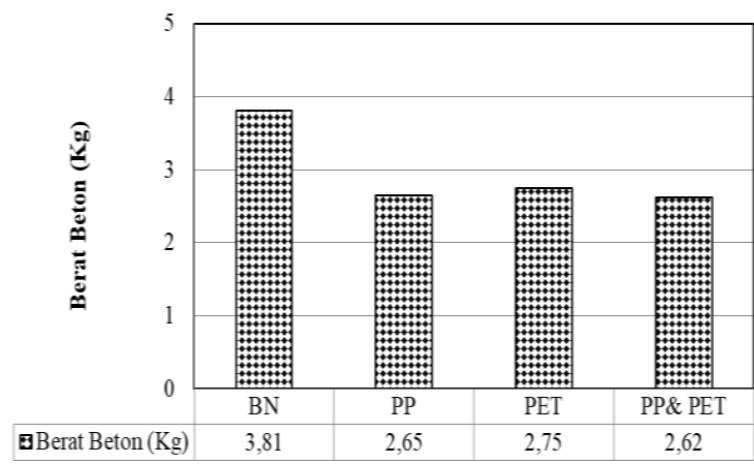

Gambar 1. Berat Beton Normal dan Beton yang Menggunakan Agregat Plastik

Gambar 1 terlihat bahwa perbandingan antara berat beton yang menggunakan agregat limbah plastik dengan jenis variasi plastik PP, PET, dan gabungan PP \& PET serta beton normal yang menggunakan agregat alam sebagai standar. Beton yang menggunakan agregat plastik yang memiliki kuat tekan tertinggi terjadi pada penggunaan agregat 
plastik PET, kemudian disusul plastik PP dan gabungan PP \& PET. Namun dibandingkan dengan beton normal maka agregat buatan plastik dapat menurunkan berat dari suatu beton. Meskipun demikian perlu dikaji bagaimana mendapatkan beton kuat dengan material yang lebih ringan.

Penurunan beton yang menggunakan agregat PP, PET dan PP \& PET adalah sebesar berturut-turut $30,40 \% ; 27,95 \%$ dan $31,28 \%$ dari nilai berat beton normal sebagai acuan. Penurunan berat beton terbesar terjadi pada penggunaan agregat daur ulang limbah plastik gabungan PP \&PET.

\subsection{Kuat Tekan Beton}

Sifat mekanik beton yang paling penting diketahui adalah kuat tekan. Kuat tekan beton merupakan besarnya beban yang dipikul oleh beton per satuan luas yang menyebabkan benda uji beton hancur jika dibebani suatu gaya tekan tertentu yang dihasilkan oleh mesin tekan. Kuat tekan beton sangat dipengaruhi oleh perbandingan semen, agregat kasar dan halus, dan air. Penelitian Erniati dkk (2015, 2016) kekuatan beton dipengaruhi oleh sifat mikrostruktur dan porositas dari suatu beton $[13,14]$.

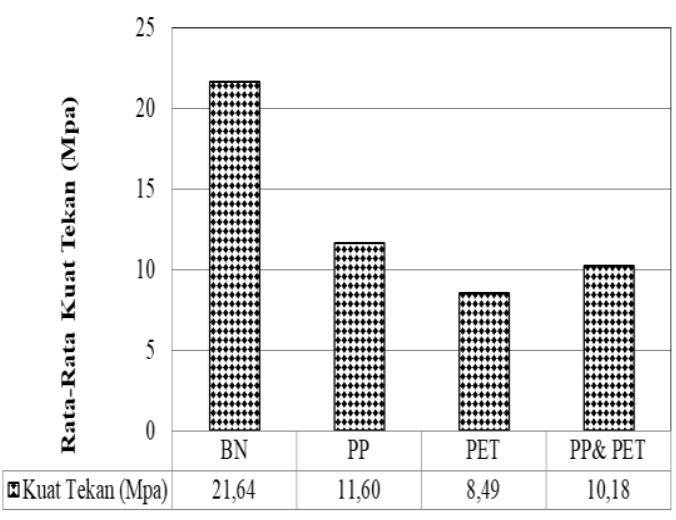

\section{Gambar 2. Kuat Tekan Beton yang Menggunakan Agregat Buatan Plastik}

Gambar 2 menunjukkan nilai rata-rata kuat tekan beton dari 3 sampel. Terlihat ada empat variasi beton yaknik beton $\mathrm{BN}$, beton PP, beton PET dan beton PP \& PET. Sampel beton BN sebagai standar memiliki kuat tekan sebesar 21,64 MPa. Variasi agregat plastik kuat tekan terbesar pada jenis beton PP dengan nilai rata-rata kuat tekan sebesar 11,60 $\mathrm{MPa}$ kemudian disusul variasi jenis beton PP \& PET sebesar 8,49 MPa.

Variasi nilai kuat tekan yang dihasilkan pada beton yang menggunakan agregat limbah plastik bervariasi itu karena agregat yang dihasilkan memiliki sifat fisik dan kegetasan yang berbeda. Penurunan kuat tekan pada beton yang menggunakan agregat plastik PP, PET dan gabungan PP \& PET berturut-turut sebesar $46,3 \%$; 60,78\%; 52,95\% dari kuat tekan beton standar 21,64 MPa. Penurunan kuat tekan beton agregat plastik terbesar terjadi pada penggunaan plastik PET. Penelitian Rommel E (2013) telah meneliti beton yang menggunakan plastik High Density Polyethylene dengan hasil bahwa kuat tekan maksimum mencapai 13,16 MPa lebih besar dibandingkan kuat tekan beton yang menggunakan plastik PP, PET dan gabungan PP \& PET [11]. Perbedaan Ini terjadi karena ada beberapa hal yakni FAS semen yang digunakan oleh Rommel E (2013) lebih kecil $(0,35)$ sedangkan penelitian ini menggunakan FAS 0,5. Disamping itu bisa saja karena sifat plastik yang berbeda sehingga itu juga mempengaruhi kekuatan suatu beton. Dengan demikian jadi melihat FAS yang digunakan masih besar, maka jadi kuat tekan yang menggunakan limbah plastik PP, PET dan gabungan PP \& PET masih bisa ditingkatkan kuat tekannya dengan menurunkan FAS yang digunakan.

\subsection{Kuat Tarik Belah Beton}

Menurut Istimawan Dipohusodo bahwa beton memiliki kelebihan karena memiliki kuat tekan yang tinggi namun demikian beton juga memiliki kelemahan secara mekanis yakni kuat tarik yang rendah, kuat tarik beton sebesar sekitar 9\% - 15\% dari kuat tekannya. Nilai kuat tekan dan nilai kuat tarik bahan beton tidak berbanding lurus, setiap usaha perbaikan mutu kekuatan tekan hanya disertai peningkatan kecil nilai kuat tariknya [15].

Hasil pengujian kuat tarik belah dapat dilihat pada Gambar 3. Dimana Gambar 3 memperlihatkan perbandingan pengujian kuat tarik belah beton yang menggunakan variasi agregat plastik PP, PET, dan gabungan PP \& PET. Kuat tarik belah yang diperoleh dengan menghitung rasio beban maksimum yang diterima oleh beton dengan gaya aksial. 


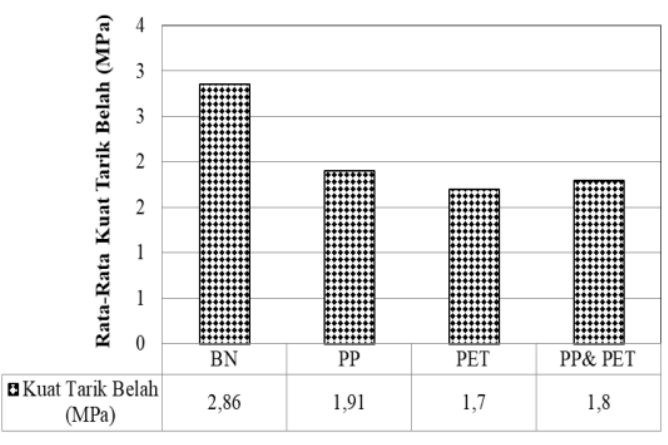

Gambar 3. Perbandingan Pengujian Kuat Tarik Belah

Beton normal yang menjadi standar/acuan dalam penelitian ini menunjukkan bahwa nilai rata-rata kuat tarik belah beton normal untuk 3 sampel memiliki nilai terbesar yaitu 2,86 MPa, sedangkan untuk variasi agregat plastik kuat tarik belah terbesar pada jenis PP, PET dan gabungan PP \& PET berturut-turut sebesar 1,91 MPa; 1,7 MPa; dan 1,8 MPa. Penurunan kuat tarik belah beton yang menggunakan plastik PP, PET, dan gabungan PP \& PET berturut-turut sebesar $33,33 \%$; 40,56\% dan 37,06\% dari kuat tarik belah beton normal 2,86 MPa.

Dalam artian dari ketiga variasi penggunaan agregat buatan plastik pada beton disimpulkan bahwa yang memiliki sifat mekanik dalam hal ini kuat tekan dan kuat tarik belah yang tertinggi adalah beton PP, sedangkan yang nilai terendah terjadi pada sampel beton PET.

\section{KESIMPULAN}

Penurunan kuat tekan pada beton yang menggunakan agregat plastik PP, PET dan gabungan PP \& PET berturut-turut sebesar $46,3 \% ; 60,78 \% ; 52,95 \%$ dari kuat tekan beton standar 21,64 MPa. Penurunan kuat tarik belah beton yang menggunakan plastik PP, PET, dan gabungan PP \& PET berturut-turut sebesar $33,33 \% ; 40,56 \%$ dan 37,06\% dari kuat tarik belah beton normal 2,86 MPa. Penggunaan $100 \%$ agregat kasar limbah plastik sebagai pengganti agregat kasar pada kuat tekan dan kuat tarik belah beton mengalami penurunan.

\section{UCAPAN TERIMAKASIH}

Terima kasih kepada Ristek Dikti atas Hibah Pascasarjana 2020 dalam membiayai penelitian ini, sehingga penelitian ini bisa berjalan dengan lancar.

\section{DAFTAR PUSTAKA}

[1] Hartono ACK. 1998. Daur Ulang Limbah Plastik dalam Pancaroba: Diplomasi Ekonomi dan Pendidikan. Dana Mitra Lingkungan. Jakarta

[2] Erniati Bachtiar, The Connection between Oven Curing Duration and Compressive Strength on C-Type Fly Ash Based Geopolymer Mortar, ARPN Journal of Engineering and Applied Sciences, 2020: Vol 15 no. 5 hal 577-582.

[3] Erniati Bachtiar, Ismail Marzuki, Asri Mulya Setiawan, Andi Muh. Nurpadli, Yusmanizar Ib Hernald, Correlation of $\mathrm{NaOH}$ Composition and Alkali Modulus to Compressive Strength on Geopolymers Mortar, ARPN Journal of Engineering and Applied Sciences, 2020: Vol 15 no.5, hal 601-606

[4] S. Das. M. T. Alam \& I Chowdhury (2016). Utilization of plastic Waste In Concrete as Partial Replacement of Fine Aggregate. Chowdhury Proceedings of 3rd International Conference on Advances in Civil Engineering. 21-23 Desember 2016. CUET. Chittagog. Bangladesh.

[5] Lestariono dan Bambang Mahendya, 2008. Penggunaan Limbah Botol Plastk (PET) sebagai Campuran Beton untuk Meningkatkan Kapasitas tarik belah dan geser, Skripsi, Fakultas Teknik. Universitas Indonesia.

[6] Fitroh Fauzi Ridwa, Subari dan Elma Yulius 2014. "Pengarug Penggunaan Cacahan Gelas Plastik Polypropylene (PP) Terhadap Kuat Tekan dan Kuat Tarik Beton" Jurnal Bentang Vol. 2 No. 1 hal 24-37, Bekasi: Universitas Islam 45 Bekasi

[7] Suwarno, Anung dan Sudarmono, 2015. Kajian Penggunaan Limbah Plastik Sebagai Campuran Agregat Beton, Wahana Teknik Sipil, No. 1 Volume 20. 1-10

[8] Bagas Soebandono, AS'Pujianto, Danar Kurniawan, Perilaku Kuat Tekan dan Kuat Tarik Beton Campuran Limbah Plastik HDPE, Jurnal Ilmiah Semesta Teknika, 2013: Vol. 16. No. 1, Universitas Muhammadiyah Yogyakarta.

[9] Supratikno dan Ratnanik, 2019. Pemanfaatan Limbah Plastik sebagai Pengganti Agregat Kasar pada Campuran Beton, Jurnal Teknik Sipil ITP Vol. 6 No. 1 Januari 2019

[10] Erniati dan Asrar, Agregat Buatan dari Daur Ulang Plastik untuk Material Penyusun Beton, 2019 (Paten, terdaftar).

[11] Erwin Rommel, 2013. Pembuatan Beton 
Ringan dari Agregat Buatan Berbahan Plastik, Jurnal Gamma, Vol 9 No. 1 september 2013

[12] Sari Utama Dewi dan Rudi Purnomo, 2016. Pengaruh Tambahan Plastik HDPE (High Density Polyethylene) terhadap Kuat Tekan Beton pada Mutu K 125, Tapak, Vol 1 No. 1 November 2016.

[13] Erniati., M.W. Tjaronge M. W., Zulharnah., and Arfan U. R. Porosity, pore size and compressive strength of self-compacting concrete using sea water, Procedia Engineering. 2015: vol 125: hal 832-837, Publisher Elsevier Ltd

[14] Erniati dan M.W. Tjaronge, Mikrostruktur Self Compacting Concrete, LeutikaPrio, Yogyakarta, 2016

[15] Dipohusodo, Istimawan. "Struktur Beton Bertulang”. PT Gramedia Pustaka Utama, Jakarta.(1996) 